\title{
Prevalence of subtypes of gastric intestinal metaplasia and its relationship with Helicobacter pylori infection
}

\author{
Sanat Chalise ${ }^{1}$, Roshan Ghimire ${ }^{2}$, Sailesh B. Pradhan ${ }^{1}$ \\ ${ }^{1}$ Department of Pathology, Kathmandu Medical College, Sinamangal, Kathmandu, Nepal \\ ${ }^{2}$ Department of Surgery, Kathmandu Medical College, Sinamangal, kathmandu, Nepal
}

\section{Keywords:}

Endoscopic biopsy; Gastric intestinal metaplasia; Helicobacter pylori;

\author{
ABSTRACT \\ Background: Gastric intestinal metaplasia is seen chronic gastritis associated with Helicobacter pylori. \\ The objective of this study was to determine the prevalence of subtypes of intestinal metaplasia and \\ presence of Helicobacter pylori infection.
}

Materials and Methods: This was a cross sectional study done at Kathmandu Medical College teaching Hospital in Pathology department from December 2018 to August 2019. The endoscopic biopsies were evaluated for intestinal metaplasia and Helicobacter pylori with the help of Hematoxylin and Eosin stains as well as Giemsa stain. Subtypes of intestinal metaplasia were classified with the help of periodic acid- Schiff/Alcian Blue stain combination and High Iron Diamine- Alcian Blue stain at pH 2.5. The relationship between Helicobacter pylori and subtypes of intestinal metaplasia were compared. Fisher's exact test was used for statistical evaluation. A p value of $<0.05$ was considered as statistically significant.

Results: The prevalence of intestinal metaplasia was found in $57(12.2 \%)$ biopsies. Type I intestinal metaplasia was found in $23(40.4 \%)$ biopsies, type II in $10(17.5 \%)$ biopsies and type III in $24(42.1 \%)$ biopsies. Helicobacter pylori was positive in 28(49.1\%) and it was negative in $29(50.9 \%)$ biopsies. No statistical significant correlation was seen in the subtypes of intestinal metaplasia with Helicobacter pylori status $(\mathrm{p}>0.05)$.

Conclusion: Intestinal metaplasia is frequently observed in endoscopic biopsies, most common being type III subtype.

\section{Correspondence:}

Dr. Sanat Chalise, $M D$

Kathmandu Medical College Public Limited,

Sinamangal, Kathmandu, Nepal

ORCID ID: 0000-0003-4735-9486

Email: chalisesanat@gmail.com

Reveived : January $2^{\text {nd }} 2020 ;$ Accepted : March $27^{\text {rd }} 2020$

Citation: Chalise S, Ghimire R, Pradhan SB. Prevalence of subtypes of gastric intestinal metaplasia and its relationship with Helicobacter pylori infection. J Pathol Nep 2020;10:1650-53 DOI 10.3126/ jpn.v10i1.28541

Copyright: This is an open-access article distributed under the terms of the Creative Commons Attribution 4.0 International License, which permits unrestricted use, distribution, and reproduction in any medium, provided the original author and source are credited.

\section{INTRODUCTION}

Gastric intestinal metaplasia (IM) is a replacement of gastric mucosal epithelium by mucosal cells with intestinal morphology and is considered as a precursor lesion for gastric cancer. ${ }^{1}$ Prevalence of gastric IM worldwide is unknown, however the study done by Sonnenberg and colleagues found $7 \%$ prevalence. $^{2}$

Based on the histomorphology and mucin-histochemistry, the gastric IM are classified as complete (type I) and incomplete (types II and III). It has been suggested that, chronic gastritis induced mainly by Helicobacter pylori $(\mathrm{H}$. pylori) infection is usually associated with IM. ${ }^{3}$ Several 
studies have shown the relation between gastric carcinoma and the subtype of IM, the incidence of cancer being highest among patients with IM subtype III. ${ }^{4-6}$

The aim of the present study was to evaluate the prevalence of IM and its subtypes in gastric biopsy specimen. We also compared the relationship between $\mathrm{H}$. pylori infection and subtypes of intestinal metaplasia.

\section{MATERIALS AND METHODS}

This was a prospective cross-sectional study conducted among patient visiting Kathmandu Medical College Public Limited, Sinamangal, Nepal from December 2018 to August 2019. The ethical approval for the study was taken from Institutional Review Committee of Kathmandu Medical College Teaching Hospital, Sinamangal. The written informed consent was obtained from each participant. The inclusion criteria include history of abdominal pain, dyspeptic symptoms, and reflux. The exclusion criteria include patient with acute upper gastrointestinal bleeding and patient with the history of gastric surgery.

All the patients who meet the above criteria and undergoing upper gastrointestinal endoscopy during the study period were included. The biopsy was taken and fixed immediately in $10 \%$ formalin solution. These were then processed in the tissue processor and embedded in paraffin wax. Serial sections were cut at $3-5 \mu$. The biopsies were stained with hematoxylin and eosin (H\&E) stain to evaluate for the presence of intestinal metaplasia. In addition Giemsa staining were carried out to determine for the presence or absence of $\mathrm{H}$. pylori. These biopsies were then stained with periodic acid- Schiff/Alcian Blue (PAS/AB) at pH 2.5 stain combination and High Iron Diamine- Alcian Blue (HID/ $\mathrm{AB})$ at $\mathrm{pH} 2.5$ stain to identify neutral mucin, sialomucin and sulphomucin. These mucin stains (PAS/AB and HID/ $\mathrm{AB}$ ) are not routinely used in histopathology for gastric biopsy samples. We used these stains to separate the types of IM. Additional cost was not charged to the patient for these stains. Subtypes of IM are determined according to Filipe et al classification. ${ }^{7}$

Type I IM is characterized by the presence of mature absorptive and goblet cells, the latter secreting acid sialomucin.

Type II IM is characterized by few or absent absorptive cells; presence of columnar intermediate cells in various stages of differentiation, secreting neutral and acid sialomucin; goblet cells secreting sialomucin and/or occasionally sulphomucin.

Type III IM cell dedifferentiation is more marked than in type II; intermediate cells secrete predominantly sulphomucin; goblet cells secrete sialo- and/or sulphomucin. A variable degree of disorganised glandular architecture is often present.

The relationship between Helicobacter pylori and subtypes of intestinal metaplasia were compared. Fisher's exact test was used for statistical evaluation. A $p$ value of $<0.05$ was considered as statistically significant.

\section{RESULTS}

We found 57 (12.2\% of 467 gastric biopsies) gastric IM. Mean age was 46.6 (range 26-72) years.

Type I gastric IM was 23 (40.4\%), type II was 10 (17.5\%) and type III was24 (42.1\%) (Table 1). Among type III gastric IM, 4(7\%) had associated dysplasia and $8(14.03 \%)$ had associated adenocarcinoma.

H. pylori was seen in 28(49.1\%) biopsies. No statistical significant difference was found in the prevalence of types of gastric IM with $\mathrm{H}$. pylori status ( $\mathrm{p}>0.05$ ) (Table 2).

On mucin histochemistry, type I IM reveals acid sialomucin in goblet cells (Figure 1A \& 1B) while acid sialomucin in goblet cells as well as mixture of neutral and acid mucin in intermediate cells was detected in type II IM (Figure 2A \& 2B). Acid sialo and sulpho mucin in goblet cells as well as sulpho mucin in intermediate cells was detected in type III IM (Fig. 3A \& 3B).

Table 1: Prevalance of subtypes of intestinal metaplasia

\begin{tabular}{lcc}
$\begin{array}{l}\text { Types of gastric } \\
\text { intestinal metaplasia }\end{array}$ & Frequency & Percent \\
\hline Type I & 23 & 40.4 \\
\hline Type II & 10 & 17.5 \\
\hline Type III & 24 & 42.1 \\
\hline Total & 57 & 100 \\
\hline
\end{tabular}

Table 2: Relationship between Helicobacter pylori and subtypes of intestinal metaplasia

\begin{tabular}{|c|c|c|c|c|c|}
\hline \multirow[t]{2}{*}{$\begin{array}{l}\text { Types of gastric intestinal } \\
\text { metaplasia }\end{array}$} & \multicolumn{3}{|c|}{$\begin{array}{l}\text { Frequency } \\
\text { Percent }\end{array}$} & \multirow[t]{2}{*}{ Total } & $\begin{array}{c}\text { Fisher's exact test } \\
\text { p value }\end{array}$ \\
\hline & Type I & Type II & Type II & & \multirow{4}{*}{0.305} \\
\hline Positive & $13(56.5 \%)$ & $6(60.0 \%)$ & $9(37.5 \%)$ & $28(49.1 \%)$ & \\
\hline Negative & $10(43.5 \%)$ & $4(40.0 \%)$ & $15(62.5 \%)$ & $29(50.9 \%)$ & \\
\hline Total & $23(100 \%)$ & $10(100 \%)$ & $24(100 \%)$ & $57(100 \%)$ & \\
\hline
\end{tabular}




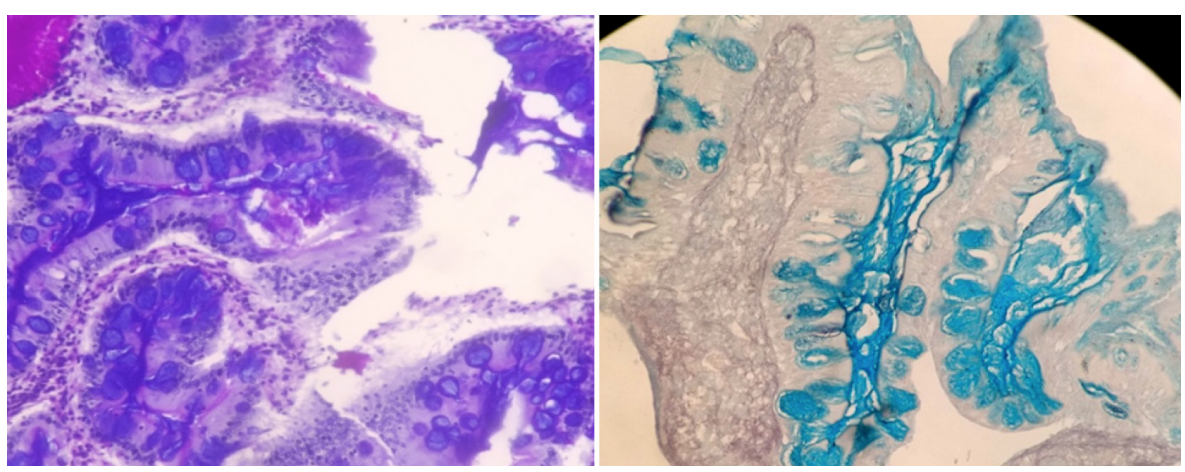

Figure 1: Intestinal metaplasia Type I: (A) PAS/AB stain, goblet cells secreting acid sialomucin. (B)HID-AB stain, absorptive cells mucin is predominantly neutral mucin (unstained) and goblet cells secreting sialomucin. (Magnification, X400)

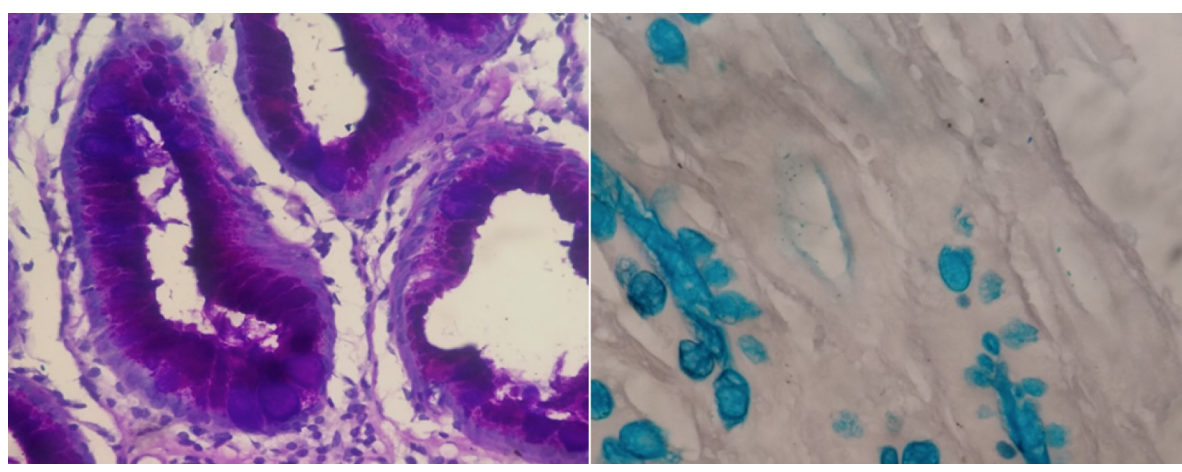

Figure 2: Intestinal metaplasia Type II: (A) PAS/AB stain, goblet cells secreting acid mucin and intermediate cells in between contain a mixture of neutral and acid mucins. (B)HID-AB stain, intermediate cells mucin is predominantly neutral mucin (unstained). (Magnification, X400)

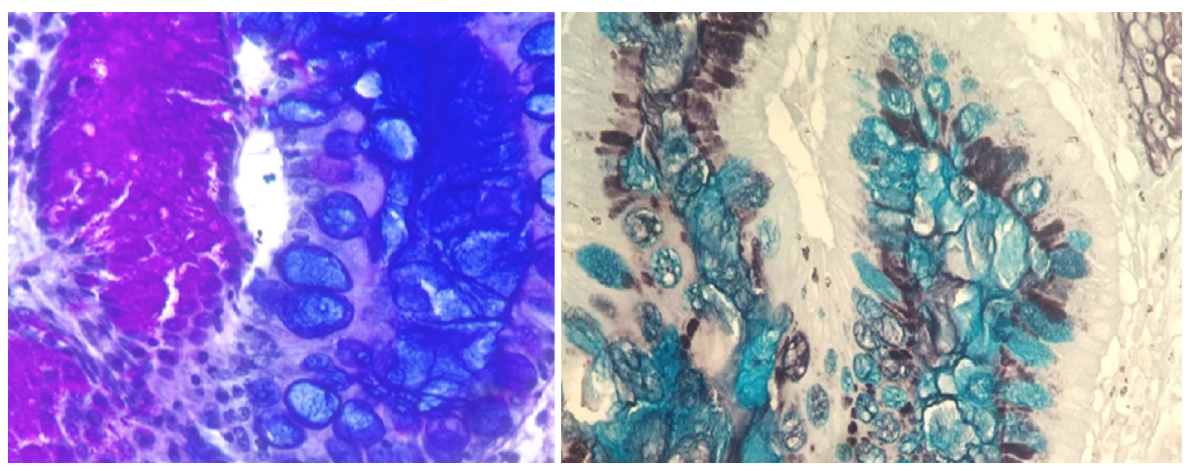

Figure 3: Intestinal metaplasia Type III: (A) PAS/AB stain, goblet cells secreting acid mucin (B)HID-AB stain, intermediate cells mucin is predominantly sulphomucin (brown) and goblet cell secreting sialo (blue) and sulpho (brown) mucin. (Magnification, X400)

\section{DISCUSSION}

The prevalence of gastric IM was found to be $12.2 \%$ in our study which is similar to the reported prevalence. ${ }^{1,8}$ However in contrast to our study low prevalence of IM was observed in other studies, the possible cause for this might be less prevalence of H. pylori infection in their countries. ${ }^{2,9}$

In a research of prevalence of gastric IM done in Turkey, the commonest IM found was type III (38\%), followed by type II $(32 \%)$ and type I $(8.2 \%) .1 \mathrm{We}$ also found type
III as a commonest gastric IM. However in other studies done in Finland and Netherland higher prevalence of type I IM was reported. ${ }^{6,10}$ This might be because we had higher prevalence of $\mathrm{H}$. pylori infection and also the $\mathrm{H}$. pylori eradication program was not active in our country.

It has been emphasized that sulphomucin secreting IM, that is type III is found significantly more often in surrounding dysplasia and gastric adenocarcinoma. ${ }^{11}$ In our study we also found type III IM associated with dysplasia and adenocarcinoma in $4(7 \%)$ and $8(14.03 \%)$ cases respectively. 
The cause for this late diagnosis in our country is because patients were reluctant to do endoscopy and biopsy as per protocol for the early detection of precancerous lesions. Several studies suggested that routine endoscopic evaluation and histopathological follow up could be cost effective in patient with IM as this could detect gastric cancer at an early stage. ${ }^{12-13}$ Recently published updated guidelines 2019 for the management of epithelial precancerous conditions and lesions in the stomach (MAPSII) recommend that patients with IM at a single location but with a family history of gastric cancer, incomplete IM, or persistent $\mathrm{H}$. pylori gastritis, endoscopic surveillance with chromoendoscopy and guided biopsies may be considered in 3 years. ${ }^{14}$

This study showed H. pylori was positive in 28 (49.1\%) cases with gastric IM. Significant difference was not found between types of IM with $\mathrm{H}$. pylori infection $(\mathrm{p}>0.05)$. We found type III subtype was lower in H. pylori positive case than in $\mathrm{H}$. pylori negative which suggest that gastric environment is not suitable for H. pylori in type III IM positive patient. Similar type of result was found in other studies. ${ }^{1,10}$ It has been postulated that H. pylori causes chronic gastritis and may progress over years to atrophic gastritis. IM, which is considered as a premalignant lesion arising in the background of atrophic gastritis finally leads to dysplasia and carcinoma. ${ }^{15}$

\section{CONCLUSIONS}

Gastric IM is a common finding in endoscopic biopsies. Type III subtype is more commonly observed than other subtypes. H. pylori can be absent in type III IM because of alteration in gastric environment. The practice of using $\mathrm{PAS} / \mathrm{AB}$ and $\mathrm{HID} / \mathrm{AB}$ stain is essential in routine histopathological examination to differentiate subtypes of IM.

\section{Acknowledgement}

We would like to thank Pathology residents and laboratory staffs of Kathmandu Medical College for cooperation to do special stain in the study.

\section{Conflict of Interest: None}

\section{REFERENCES}

1. Olmez S, Aslan M, Erten R, Sayar S, Bayram I. The Prevalence of Gastric Intestinal Metaplasia and Distribution of Helicobacter pylori Infection, Atrophy, Dysplasia, and Cancer in Its Subtypes. Gastroenterology Research and Practice 2015;2015:1-6. Crossref

2. Sonnenberg A, Lash RH, Genta RM. A National Study of Helicobactor pylori Infection in Gastric Biopsy Specimens. Gastroenterology 2010;139:1894-1901. Crossref
3. Petersson F, Borch K, Franzén LE. Prevalence of Subtypes of Intestinal Metaplasia in the General Population and in Patients with Autoimmune Chronic Atrophic Gastritis. Scandinavian Journal of Gastroenterology 2002;37:262-6. Crossref

4. Jencks DS, Adam JD, Borum ML, Koh JM, Stephen S, Doman DB. Overview of Current Concepts in Gastric Intestinal Metaplasia and Gastric Cancer. Gastroenterol Hepatol 2018;14:92-101. Website

5. El-Zimaity HMT, Ramchatesingh J, Ali Saeed M, Graham DY. Gastric intestinal metaplasia: subtypes and natural history. Journal of Clinical Pathology 2001;54:679-83. Crossref

6. Eriksson NK, Kärkkäinen PA, Färkkilä MA, Arkkila PET. Prevalence and distribution of gastric intestinal metaplasia and its subtypes. Digestive and Liver Disease 2008;40:355-60. Crossref

7. Filipe MI, Potet F, Bogomoletz WV, Dawson PA, Fabiani B, Chauveinc $\mathrm{P}$, et al. Incomplete sulphomucin-secreting intestinal metaplasia for gastric cancer. Preliminary data from a prospective study from three centres. Gut 1985;26:1319-26. Crossref

8. Almouradi T, Hiatt T, Attar B. Gastric Intestinal Metaplasia in an Underserved Population in the USA: Prevalence, Epidemiologic and Clinical Features. Gastroenterology Research and Practice 2013;2013:1-4. Crossref

9. de Vries AC, van Grieken NCT, Looman CWN, Casparie MK, de Vries E, Meijer GA, et al. Gastric Cancer Risk in Patients With Premalignant Gastric Lesions: A Nationwide Cohort Study in the Netherlands. Gastroenterology 2008;134:945-52. Crossref

10. Craanen ME, Blok P, Dekker W, Ferwerda J, Tytgat GN. Subtypes of intestinal metaplasia and Helicobacter pylori. Gut 1992;33:597-600. Crossref

11. Huang CB, Xu J, Huang JF, Meng XY. Sulphomucin colonic type intestinal metaplasia and carcinoma in the stomach. A histochemical study of 115 cases obtained by biopsy. Cancer 1986;57:1370-5. Crossref

12. Zullo A, Hassan C, Romiti A, Giusto M, Guerriero C, Lorenzetti R, et al. Follow-up of intestinal metaplasia in the stomach: When, how and why. World J Gastrointest Oncol 2012;4:30-6. Crossref

13. Whiting JL, Sigurdsson A, Rowlands DC, Hallissey MT, Fielding JWL. The long term results of endoscopic surveillance of premalignant gastric lesions. Gut 2002;50:378-81. Crossref

14. Pimentel-Nunes P, Libânio D, Marcos-Pinto R, Areia M, Leja M, Esposito $\mathrm{G}$ et al. Management of epithelial precancerous conditions and lesions in the stomach (MAPS II): European Society of Gastrointestinal Endoscopy (ESGE), European Helicobacter and Microbiota Study Group (EHMSG), European Society of Pathology (ESP) and Sociedade Portuguesa de Endoscopia Digestiva (SPED) guideline update 2019. Endoscopy 2019;51:365-388. Crossref

15. Correa P. Human gastric carcinogenesis: a multistep and multifactorial process-- First American Cancer Society Award Lecture on Cancer Epidemiology and Prevention. Cancer Res 1992;52:6735-40. Website 